Plant Tissue Cult. \& Biotech. 17(1): 65-70, 2007 (June)

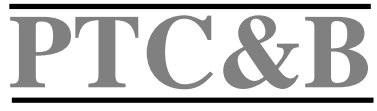

\title{
Embryogenic Callus Induction and Regeneration of Elite Bangladeshi Indica Rice Cultivars
}

\author{
M. E. Hoque, M. S. Ali and N. H. Karim \\ Biotechnology Division, Bangladesh Rice Research Institute, Gazipur-1701, Bangladesh
}

Key words: Indica rice, Callus induction, Plant regeneration, Genotypic variations

\begin{abstract}
Significant variations were observed among six elite Bangladeshi Indica rice cultivars tested in relation to total callus induction frequency $(p=0.017)$, embryogenic callus formation frequency $(p=0.001)$ and subsequent plant regeneration responses $(p=0.005)$. In all the cases, embryogenic callus formation frequency was much more less than the total callus (embryogenic + nonembryonegic) formation frequency. The embryogenic calli derived from mature seed embryos produced green plants, successfully established in soil and produced fertile seeds.
\end{abstract}

\section{Introduction}

Rice (Oryza sativa L.) is the staple food for the people of Bangladesh. Rice provides as much as $80 \%$ of the required calories for its people. Presently rice production is very close to its requirement, but due to continuous increase in population growth rate there is an enormous need for further increase. It is generally assumed that for densely populated countries of the world like Bangladesh, the probability of increasing cultivable land is nearly zero. The only alternative, therefore, is to increase productivity. The application of biotechnology in combination with conventional breeding methods will ease the gigantic task of increasing food production. Many features of biotechnology today are directed towards improvement of conventional plant breeding processes, such as introduction of novel genes by genetic transformation, protoplast fusion for production of male sterile lines, haploid generation for attaining rapid homozygosity and somaclonal variation for introducing increasing trait variability.

Efficient plant regeneration in vitro is essential for the successful utilization of biotechnology in rice crop improvement (Hoque 2002). It is often difficult to establish embryogenic cell cultures and to regenerate plants from these cultured cells specially those belonging to Indica subspecies (Jain 1997). Even within the Indica group, there are significant variation in the in vitro culture responses 
among different genotypes (Khanna and Raina 1998). The recalcitrant nature of this subspecies has, in fact, been a major limiting factor in the transfer of available useful genes (Toenniessen 1991). Therefore, the identification and screening of useful cultivars for embryogenic callus formation and subsequent plant regeneration in vitro are key steps in rice genetic improvement program through application of biotechnology (Hoque and Mansfield 2004).

In rice, in vitro plant regeneration has been obtained from almost all types of explants (Jain 1997). However, significant variation was observed in embryogenic callus production, somatic embryogenesis and subsequent plant regeneration from different origin (Rueb et al. 1994). The use of mature seed embryos has distinct advantage over other explants as staring material for in vitro regeneration. Moreover, embryogenic calli obtained from mature seed embryos are efficient in Indica rice transformation (Hoque 2002). Therefore, the purpose of the present study was to develop an efficient and reproducible plant regeneration system in vitro from mature seed embryos of selected Bangladeshi Indica rice cultivars for future rice crop improvement program.

\section{Materials and Methods}

Six elite Bangladeshi Indica rice (Oryza sativa L.) cultivars such as BR14, BRRI dhan28, BRRI dhan29, BRRI dhan38, BRRI dhan39 and BRRI dhan40 and one responsive Japonica rice cultivar Taipei-309 were used for callus induction and subsequent plant regeneration. Japonica rice cultivar Taipei-309 was included for comparison only.

Dehusked seeds were first washed in distilled water mixed with Tween 20 (one drop/30 $\mathrm{ml}$ of water) for ten min and then steeped in $70 \%(\mathrm{v} / \mathrm{v})$ ethanol for two min with gentle agitation followed by rinsing three times with sterile distilled water. The seeds were then surface sterilized in $0.1 \%(\mathrm{w} / \mathrm{v}) \mathrm{HgCl}_{2}$ for 15 min with gentle agitation and rinsed five times with sterile distilled water. Sterilized seeds were incubated for callus induction (Fig. 1a) in Petri dishes containing callus induction medium (CIM), which included MS basal medium supplemented with $2.0 \mathrm{mg} / 1$ 2,4-D, $20.0 \mathrm{~g} / 1$ sucrose and gelled with $8.0 \mathrm{~g} / 1$ agar. The $\mathrm{pH}$ was adjusted to 5.8 before autoclaving. The Petri dishes were sealed with Para film and incubated at $25 \pm 1{ }^{\circ} \mathrm{C}$ in the dark for four weeks before callus induction responses were assessed. After four weeks of incubation, data were taken on total callus induction frequency (embryogenic + non-embryogenic) along with that of embryogenic calli. Only embryogenic calli were transferred to fresh CIM for multiplication. Subculture was carried out once every two weeks. Callus (total/embryogenic) induction frequency (\%) for each genotype was calculated by dividing the total number seeds produced callus (total/ embryogenic) by the total number of seeds plated and multiplied by 100 . 
Regeneration medium was based on the formulation of MS basal salt supplemented with $1.0 \mathrm{NAA} \mathrm{mg} / 1,1.0 \mathrm{mg} / 1 \mathrm{Kn}, 40.0 \mathrm{~g} / 1$ sucrose and gelled with $8.0 \mathrm{~g} / 1$ agar. The $\mathrm{pH}$ of the medium was adjusted to 5.8 before sterilization. For regeneration, eight-week-old embryogenic calli were placed into Petri dishes, each containing $15 \mathrm{ml}$ regeneration medium. All such cultures were kept at $25 \pm$ $1^{\circ} \mathrm{C}$ under continuous light from fluorescent lamps. Data on shoot regeneration were collected eight weeks after transfer of calli. Regenerated shoots were transferred to hormone free half strength semisolid MS for vigorous root development. Well developed rooted plantlets were transferred into soil and grown in the net house until maturity. The plant regeneration response (\%) for each genotype was calculated by dividing the total number of embryogenic calli producing green plants by the total number of embryogenic calli cultured and multiplied by 100 . The experiments were carried out in a completely randomized design with three replications for each genotype tested.

\section{Results and Discussion}

The initiation of callus started on the scutellum region of the seed embryo within one week and grew in size over the next three weeks on the CIM (Fig. 1b). Both embryogenic and non-embryogenic calli initiated at different frequencies. Embryogenic callus was usually light yellow to white, dry, compact and nodular, while non-embryogenic callus appeared watery, light yellow to tan and nonnodular. Significant differences were observed among the rice genotypes tested in relation to total callus (embryogenic + non-embryogrnic) induction frequency $(p=0.017)$, embryogenic callus induction frequency $(p=0.001)$ and per cent plant regeneration frequency $(\mathrm{p}=0.005)$. Total callus induction frequency ranged from 60.5 to $76.3 \%$, while embryogenic callus induction frequency ranged from 25.4 to $54.5 \%$ (Table 1). The highest rate of embryogenic callus production was found in BRRI dhan38 followed by Japonica rice cultivar Taipei-309 and BRRI dhan39 (Table 1). This is in agreement with previous reports in which embryogenic and non-embryogenic callus formation as well as plant regeneration is reported to be genetically determined as described for different cereals including rice (Khalequzzaman et al. 2005, Hoque and Mansfield 2004, Khanna and Raina 1998), wheat (Özgen et al. 1998) and barley (Lührs and Lörz 1987).

After transfer of embryogenic calli to the regeneration medium, green areas began to develop on callus surfaces within two - three weeks; thereafter the green plants developed from these green areas (Fig. 1c). At about the same time some calli began to turn brown and died. Three weeks old in vitro regenerated plants were placed into half strength MS for vigorous root development before transferring them to soil (Fig. 1d, e). In regeneration, striking differences were 
observed between the genotypes tested. Of all the genotypes, Japonica rice cultivar Taipei-309 showed the best results in regeneration medium followed by BRRI dhan38 and BRRI dhan39 (Table 2). It is therefore, recommended that suitable genotypes should be used to increase the plant regeneration frequency in rice tissue culture.

Table 1. Callus induction frequency of six elite Bangladeshi Indica rice cultivars.

\begin{tabular}{|c|c|c|c|c|c|}
\hline Cultivars & $\begin{array}{c}\text { No. of } \\
\text { seeds } \\
\text { incubated }\end{array}$ & $\begin{array}{c}\text { No. of seeds } \\
\text { produced callus } \\
\text { (embryogenic }+ \\
\text { non- } \\
\text { embryogenic) }\end{array}$ & $\begin{array}{l}\text { Total } \\
\text { callus } \\
\text { induction } \\
\text { frequency } \\
\text { (\%) }\end{array}$ & $\begin{array}{c}\text { No. of } \\
\text { seeds } \\
\text { produced } \\
\text { embryo- } \\
\text { genic callus }\end{array}$ & $\begin{array}{c}\text { Embryogenic } \\
\text { callus } \\
\text { induction } \\
\text { frequency }(\%)\end{array}$ \\
\hline BR 14 & 184 & 114 & 62.0 & 62 & 33.7 \\
\hline BRRI dhan28 & 209 & 149 & 71.3 & 53 & 25.4 \\
\hline BRRI dhan29 & 215 & 133 & 61.9 & 88 & 40.9 \\
\hline BRRI dhan38 & 224 & 171 & 76.3 & 122 & 54.5 \\
\hline BRRI dhan39 & 218 & 143 & 65.6 & 97 & 44.5 \\
\hline BRRI dhan 40 & 200 & 121 & 60.5 & 64 & 32.0 \\
\hline $\begin{array}{l}\text { Taipei-309 } \\
\text { (Control) }\end{array}$ & 230 & 174 & 75.7 & 116 & 50.4 \\
\hline \multirow{3}{*}{$\begin{array}{l}\text { One-way } \\
\text { ANOVA }\end{array}$} & \multicolumn{3}{|c|}{$p=0.017$} & \multirow{2}{*}{\multicolumn{2}{|c|}{$\begin{array}{c}p=0.001 \\
\operatorname{LSD}(5 \%)=10.35\end{array}$}} \\
\hline & \multicolumn{3}{|c|}{$\operatorname{LSD}(5 \%)=10.17$} & & \\
\hline & \multicolumn{3}{|c|}{$\mathrm{CV}(\%)=8.5$} & \multicolumn{2}{|r|}{$\mathrm{CV}(\%)=14.5$} \\
\hline
\end{tabular}

Table 2. Plant regeneration response of six elite Bangladeshi Indica rice cultivars

\begin{tabular}{lccc}
\hline Cultivars & $\begin{array}{c}\text { No. of } \\
\text { embryogenic } \\
\text { callus incubated }\end{array}$ & $\begin{array}{c}\text { No. of calli } \\
\text { produced green } \\
\text { plant }\end{array}$ & $\begin{array}{c}\text { Plant } \\
\text { regeneration } \\
\text { frequency (\%) }\end{array}$ \\
\hline BR 14 & 62 & 14 & 22.6 \\
BRRI dhan28 & 53 & 11 & 20.8 \\
BRRI dhan29 & 88 & 31 & 35.2 \\
BRRI dhan38 & 122 & 54 & 44.3 \\
BRRI dhan39 & 97 & 42 & 43.3 \\
BRRI dhan40 & 64 & 12 & 18.8 \\
Taipei-309 (Control) & 116 & 53 & 45.7 \\
\hline & & & $\mathrm{p}=0.005$ \\
One-way ANOVA & & & $\mathrm{LSD}(5 \%)=14.77$ \\
& & & $\mathrm{CV}(\%)=24.9$ \\
\hline
\end{tabular}

Abe and Futsuhara (1986) and Hartke and Lörz (1989) have reported that many Japonica rice cultivars respond better both in callus formation and plant regeneration than the Indica rice varieties. The results reported in the present study reveal that this is not always so. One Indica rice cultivar BRRI dhan38 
responded better in terms of total callus formation and initiation of embryogenic callus, compared to the responsive Japonica rice cultivar Taipei-309, suggesting that callogenesis is not specific to the subspecies, but governed by overall genotypic differences. These variations might be due to differences in the components and concentrations of endogenous phytohormones, and differences in their responsiveness to 2,4-D between Indica and Japonica varieties (Sundaru et al. 1983).
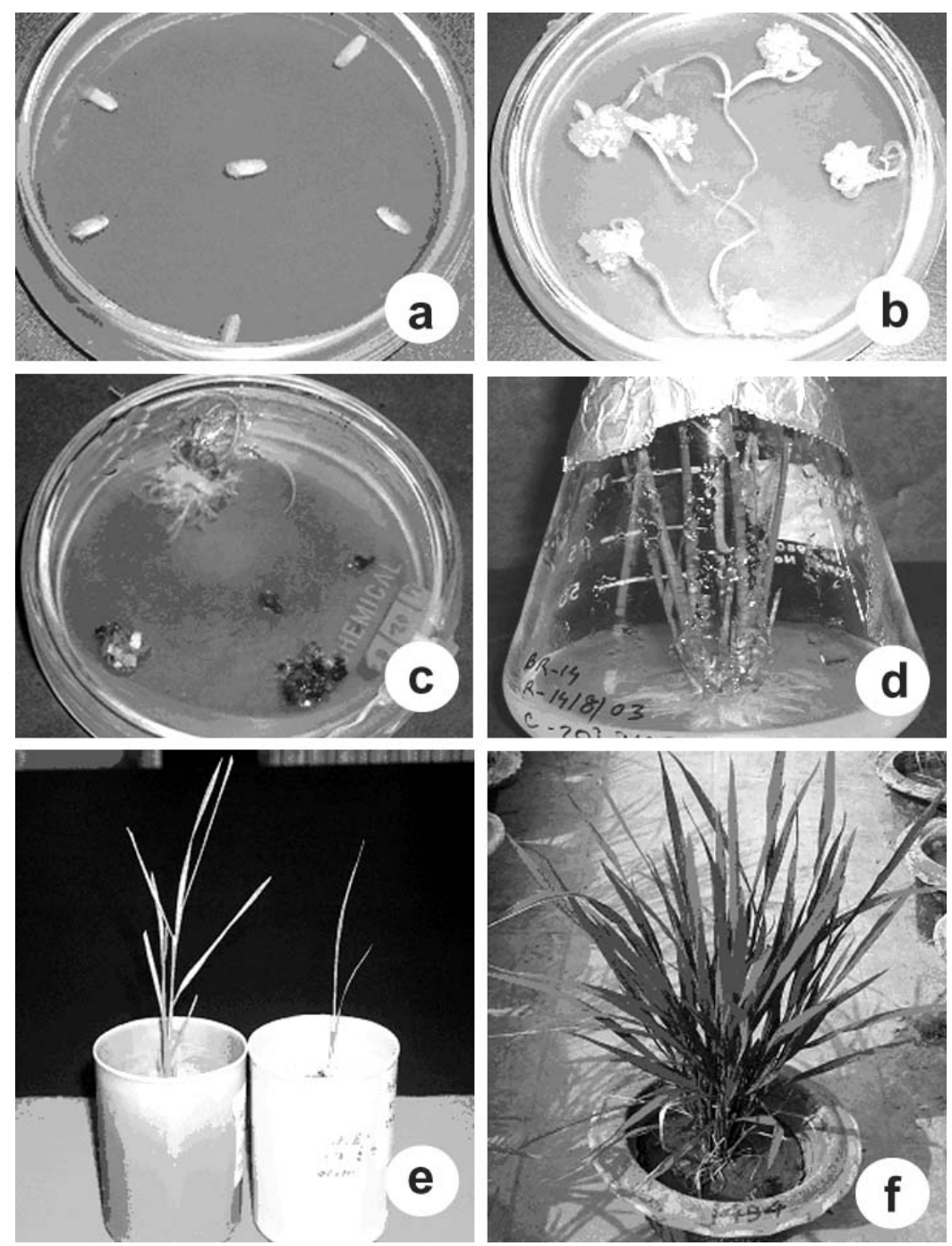

Fig. 1. Plant regeneration from mature embryo-derived embryogenic calli: (a) sterilized seeds planted for callus induction, (b) callus induction from mature seed embryos, (c) plant regenerated from embryo-genic callus, (d) rice plant in rooting medium, (e) 
regenerated plants transferred to small pots for hardening and (f) a well established in vitro regenerated rice plant in soil.

It may be concluded that genotypic differences strongly influence on callus formation and plant regeneration potential. The results suggest that embryogenic callus obtained from mature seed embryos is a very good source material for efficient in vitro plant regeneration. The identification of these genotypes with superior tissue culture performance is a key step in gene transfer in rice biotechnology.

\section{References}

Abe T and Futsuhara Y (1986) Genotypic variability for callus formation and plant regeneration in rice (Oryza sativa L.). Theor. Appl. Genet. 72: 3-10.

Hartke S and Lörz H (1989) Somatic embryogenesis and plant regeneration from various Indica rice (Oryza sativa L.) genotypes. J. Genet. Breed. 43: 205-214.

Hoque EH (2002) Development of Agrobacterium-mediated transformation of rice (Oryza sativa L.) genotypes grown in Bangladesh. PhD thesis, University of London, UK.

Hoque EH and Mansfield JW (2004) Effect of genotype and explant age on callus induction and subsequent plant regeneration from root-derived callus of Indica rice genotypes. Plant Cell Tiss. Org. Cult.78: 217-223.

Jain RK (1997) Effect of some factors on plant regeneration from Indica rice cells and protoplasts - a review. Indian J. Exp. Biol. 35: 323-331.

Khalequzzaman M, Haq N, Hoque ME and Aditya TL (2005) Regeneration efficiency and genotypic effect of 15 Indica type Bangladeshi rice (Oryza sativa L.) landraces. Plant Tissue Cult. 15: 33-42

Khanna HK and Raina SK (1998) Genotype $\times$ culture media interaction effects on regeneration response of three Indica rice cultivars. Plant Cell Tiss. Org. Cult. 52: 145153.

Lührs R and Lörz H (1987) Plant regeneration in vitro from embryogenic cultures of spring- and winter-type barley (Hordeum vulgare L.) varieties. Theor. Appl. Genet. 75: 16-25.

Özgen M, Türet M, Altinok S and Sancak C (1998) Efficient callus induction and plant regeneration from mature embryo culture of winter wheat (Triticum asetivum L.) genotypes. Plant Cell Rep. 18: 331-335.

Rueb S, Leneman M, Schilperoot RA and Hensgens LAM (1994) Efficient plant regeneration through somatic embryogenesis from callus induced on mature rice embryos (Oryza sativa L.). Plant Cell Tiss. Org. Cult. 36: 259-264.

Sundaru M, Baba I, Tami F and Motoda Y (1983) Varietal difference of Indonesian rice plants in their susceptability to 2,4-D injury and interrelationships with ethylene. Japanese J. Crop Sci. 52: 323-330.

Toenniessen GH (1991) Potentially useful genes for rice genetic engineering. In: Rice Biotechnology, Khush GS and Toenniessen GH (Eds.), CAB International and IRRI, Wallingford/Manila, pp. 253-280. 
Embryogenic Callus Induction and Regeneration 